\title{
Yerba Mate (Ilex paraguariensis) Beverage: Nutraceutical Ingredient or Conveyor for the Intake of Medicinal Plants? Evidence from Paraguayan Folk Medicine
}

\author{
Monika Kujawska \\ Institute of Ethnology and Cultural Anthropology, University of Lodz, ul. Lindleya 3/5, 90-131 Lodz, Poland \\ Correspondence should be addressed to Monika Kujawska; monikakujawska@gmail.com
}

Received 29 November 2017; Accepted 7 February 2018; Published 14 March 2018

Academic Editor: Rainer W. Bussmann

Copyright (C) 2018 Monika Kujawska. This is an open access article distributed under the Creative Commons Attribution License, which permits unrestricted use, distribution, and reproduction in any medium, provided the original work is properly cited.

The use of medicinal plants mixed with yerba mate (Ilex paraguariensis) has been poorly studied in the ethnopharmacological literature so far. The Paraguayan Mestizo people have the longest tradition of using the yerba mate beverage, apart from the indigenous Guarani people. This study analyses the role of yerba mate and medicinal plants in the treatment of illnesses within Paraguayan folk medicine. The research was conducted among 100 Paraguayan migrants living in Misiones, Argentina, in 2014 and 2015. Yerba mate is not considered to be a medicinal plant by its own virtues but is culturally a very important type of medicinal plant intake. Ninety-seven species are employed in hot and cold versions of the yerba mate beverage. The most important species are as follows: Allophylus edulis (highest number of citations), Aristolochia triangularis (highest relative importance value), and Achyrocline flaccida and Achyrocline tomentosa (highest score by Index of Agreement on Species). The plants are used in the treatment of 18 medicinal categories, which include illnesses traditionally treated with plants: digestive system, humoral medicine, and relatively new health conditions such as diabetes, hypertension, and high levels of cholesterol. Newly incorporated medicinal plants, such as Moringa oleifera, are ingested predominantly or exclusively with the mate beverage.

\section{Introduction}

Yerba mate (Ilex paraguariensis A.St.-Hil., Aquifoliaceae) is a native tree growing in the subtropics of South America, present in Southern Brazil, Northeastern Argentina, Eastern Paraguay, and Uruguay [1]. The yerba mate beverage has been consumed traditionally by Guarani indigenous people since before the conquest of South America by the Spaniards [2]. The commercial potential of this plant was discovered by the Jesuits, who brought wild growing yerba mate into cultivation. Pedro de Montenegro, a Jesuit monk, in his Materia Medica Misionera described the use of the most important species for the Guarani people, in which yerba mate appeared on the top of the list [3]. The Guarani name for yerba mate is ka'a which means "a plant" or "a herb"; hence yerba mate has been considered by this group as the plant par excellence [3]. Yerba mate was also known as Jesuit tea or Paraguayan tea and shipped as such to Europe [2]. With the expulsion of the Jesuits in 1768, the plantations went wild. By this time, the yerba mate beverage was already popular among Mestizo people (of Spanish and Guarani origin). Since the end of the 19th century, it also became a daily beverage for the European migrants who partly colonized Southern Brazil, Northeastern Argentina, and, to a lesser extent, Eastern Paraguay [4]. Nowadays yerba mate is consumed at the rate of more than one litre per day by millions of people in the abovementioned countries $[4,5]$. It plays a very special social role and constitutes a very important form of caffeine intake [2, $4,5]$. Its popularity is also increasing outside South America due to its pharmacological properties, proven to be beneficial to health $[4,6,7]$. It is also a very important drink in Syria and Lebanon due to Syro-Lebanese migration to Argentina in the second half of the 19th century. Many migrants who returned to the Levant in the 1920s took the habit of drinking mate with them $[8,9]$. 
Over the last 20 years there has been an increase in studies of the pharmacologic properties of Ilex paraguariensis, which have been reviewed $[4,6,7,10]$. Numerous active compounds have been identified in yerba mate. Phenolic compounds predominate caffeoyl derivatives (caffeic acid, chlorogenic acid) $[11,12]$, xanthines (caffeine and theobromine), which are a class of purine alkaloids found in many other plants such as tea and coffee, flavonoids (quercetin, kaempferol, and rutin), and tannins [7]. Numerous triterpenoid saponins have also been identified, including those derived from ursolic acids known as metasaponins [4, 7]. Saponins are responsible for the distinct flavour of yerba mate extracts [7]. Yerba mate also contains minerals (P, Fe, and $\mathrm{Ca})$ and vitamins (C, B1, and B2) [13].

Research on extracts and isolated compounds from yerba mate has provided a number of pharmacological applications. Studies have demonstrated that yerba mate leaves have antioxidant [11], antiobesity $[14,15]$, antidiabetic, digestive improvement and cardiovascular properties [16, 17], and chemopreventative ones (preventing cellular damage that may cause chronic diseases) [18]. The consumption of yerba mate infusion reduces LDL-cholesterol in parallel with an increase in HDL-cholesterol, as observed in studies on humans [19]. Yerba mate extract also reduces acute lung inflammation, as observed in the animal model [4]. Antimicrobial activity of Ilex paraguariensis has been recently studied as well [20].

Some ethnobotanical studies from the south cone of South America report medicinal uses of yerba mate beverage $[21,22]$. Few ethnobotanical and ethnopharmacological studies mention that various medicinal plants are consumed together with the yerba mate beverage by Mestizo and European migrants living in Argentina and Paraguay [2326]. However, very little is known about how medicinal plants are combined with yerba mate beverage by local people. Additionally, medicinal plant use by Paraguayan Mestizo people is poorly documented in the English-language scientific literature, with very few exceptions [23, 26-30]. The documentation of medicinal plants and analysis of traditional knowledge related to the yerba mate beverage by Paraguayan Mestizo people is of paramount importance for two reasons: (1) apart from indigenous Guarani peoples, they have the longest tradition of using yerba mate and mixing it with medicinal plants; (2) The Paraguayan people are described in the literature as knowledgeable about medicinal plants $[30,31]$. Nearly $80 \%$ of the population of Paraguay consume medicinal plants on a daily basis [30]. However, the relationship between traditional uses and pharmaceutical properties is poorly studied.

The objectives of this contribution were to (1) document and analyse the role of yerba mate in prophylaxis and treatment by Paraguayan Mestizo people; (2) evaluate the role of medicinal plants in yerba mate beverages, and (3) describe the scope of illnesses treated with yerba mate beverage and medicinal plants. Additionally, two questions guided my research and analysis: (1) Does any pattern exist showing that particular illnesses are treated with a hot version of yerba mate beverage and others with a cold one? (2) How receptive is this traditional mode of plant administration to new health challenges and new medicinal plants, previously unknown to the Paraguayan people?

\section{Material and Methods}

2.1. Study Area and Ethnographic Setting. The research was conducted among Paraguayan migrants living in the province of Misiones, Argentina. Misiones borders with Paraguay and Brazil and is primarily a semideciduous Atlantic Forest. The Atlantic Forest is one of the most diverse ecosystems in the world [32]. The climate is subtropical humid with no dry seasons, a mean annual rainfall of $2,000 \mathrm{~mm}$, and a mean annual temperature of $20^{\circ} \mathrm{C}$ [33]. Currently, nearly $40 \%$ of original forest cover is preserved in Argentina, in contrast to Brazil and Paraguay, where it comprises approximately $8 \%$ [34]. The flora of Misiones comprise 3000 vascular plants, of which more than 500 species have been used for phytotherapeutic purposes by the different ethnic groups living there: the indigenous Guarani people, Mestizos of different origins (Argentinean, Paraguayan, and Brazilian) and European migrants [35].

The colonial policy in Paraguay, which was based not on mineral extraction but on settlement, resulted in the early emergence of an entirely new Paraguayan Mestizo culture, neither Spanish nor Guarani, but influenced by both of them $[36,37]$. Within Mestizo culture, the Guarani language was preserved, as well as native customs and knowledge. Paraguayan Mestizo people have had the contact with European phytotherapeutic traditions since early colonial times, when they were introduced by Catholic nuns and monks, who promoted the use of well-known medicinal plants from the Mediterranean region, such as Artemisia, Ruta, Mentha, and Rosmarinus, as well as Asian species, such as Cymbopogon citratus and Citrus spp. [38]. The basic Hippocratic and humoral concepts were introduced through the same channels $[39,40]$.

Since the 19th century, Criollos (the local name for Mestizos) have been coming to Misiones from Paraguay. According to the 2010 census, the Paraguayan community in Argentina accounts for 550.713 persons. This figure represents $30.5 \%$ of all immigrants in the country and approximately $8.6 \%$ of the total population of Paraguay [41]. The push and pull factors for migration were both economic and political in character. Paraguayan migrants have been regarded as having low formal educational levels, especially those migrating to Argentina in the 1970s, who comprise the majority of the study population. In Misiones, Paraguayan people found employment in the agricultural and forestry sectors.

Given that in Misiones the natural environment is generally better preserved than it is in Paraguay [32], Paraguayan migrants originating from the same ecoregion of the Atlantic Forest have presumably found better conditions for implementing and transmitting their traditional ethnomedicine than they did in their own country of origin.

2.2. Data Collection. The research was conducted among 100 Paraguayan migrants, 61 women (aged between 30 and 95, mean 61) and 39 men (aged between 28 and 90, mean 61,5). Thirty-two participants were born in Misiones, Argentina, 


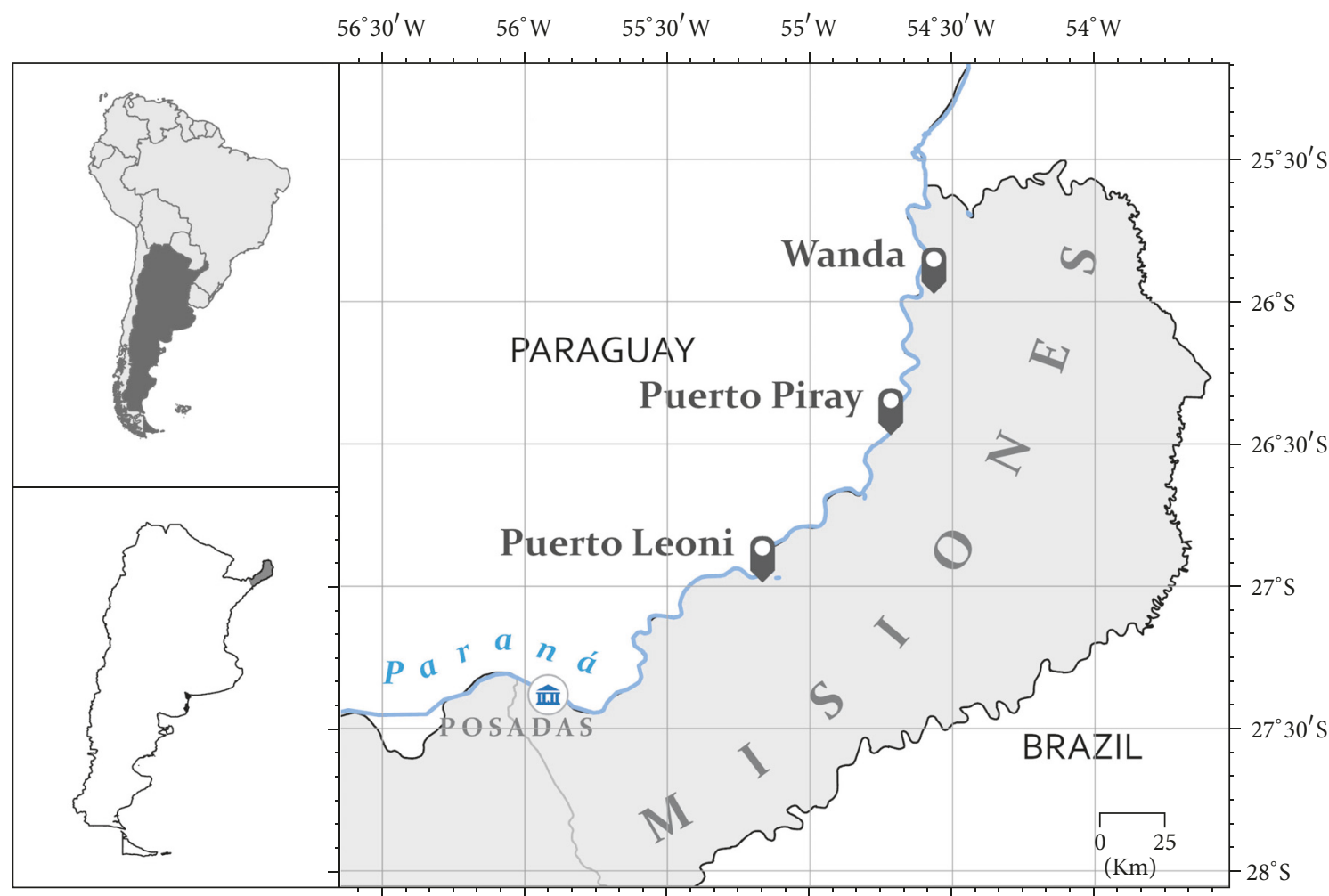

Capital of the province

Research places

- River

FIgURE 1: Distribution of the study localities, Misiones, Argentina.

while 68 hailed from the Eastern provinces of Paraguay within the same ecoregion of the Atlantic Forest. The data were collected during two phases of fieldwork, lasting three months each in 2014 and 2015. The free listing technique was applied [42]. Each informant was asked to name all the medicinal plants she/he knew and used (emphasis was placed on personal experience). When a list of names was produced, further questions were asked relating to parts used, medicinal uses, forms of administration, and modes of obtaining the plants.

The research took place in three localities, on a gradient from rural to urban, with the semirural component predominating. The three localities-Wanda with Puerto Wanda as one unit, Piray Km 18 (Puerto Piray municipality), and Puerto Leoni-are situated on the bank of the Parana River, the border between Argentina and Paraguay (Figure 1). In general terms, the study participants can be described as small scale farmers working on 1-2-hectare plots (chacras), where they cultivate staple crops such as manioc and maize. In addition, male participants usually find off-farm employment, mainly in the forestry industry.

The documented botanical taxa are supported with voucher herbarium specimens stored in the CTES herbarium in the Instituto de Botánica del Nordeste (IBONE), Corrientes, Argentina, and in the herbarium of the Museo
Argentino de Ciencias Naturales "Bernardino Rivadavia" in Buenos Aires (BA). Prior to each interview, study participants gave oral informed consent for their participation. There was no requirement for the project to pass any ethical commission, either in Argentinian or in Polish institutions, as the informants were not subject to any other treatment than voluntary interviews.

2.3. Data Analysis. In order to analyse the scope of medicinal categories, which include body systems, and determine the most important illnesses treated with yerba mate extracts, two measures were used as a proxy: number of species and use reports (UR). A use report is defined here as a description by an informant (i) of species (s) used for a medicinal purpose (p); hence two different medicinal uses of a given species reported by the same informants are counted as two use reports [43].

The relative importance (RI) value was calculated for each plant species based on the normalized number of medicinal uses attributed to it and the number of body systems/medicinal categories it treated [38]. Relative importance is a versatile index, which shows the extent of medicinal application of a given species. The reasons for versatile use of a species may be very diverse; for example, this may reflect a trial-and-error effort-a constant search for accurate or 
new medicinal applications for some widely available species. Taking this into account, another index was also used, the Index of Agreement on Species (IAS) [43], to measure the consistency of medicinal uses of a given species. This is a modified version of Index on Agreement of Remedies developed by Trotter and Logan [44].

The Sørensen similarity coefficient was used to check whether similar plants were used in the treatment of apparently similar illnesses. The formula is as follows: $\mathrm{Ss}=2 a /(2 a$ $+b+c)$, where $a$ is number of shared species, $b$ is number of exclusive species in group 1, and $c$ is number of exclusive species in group 2 . The result is then multiplied by 100 , in order to express it as a percentage.

\section{Results and Discussion}

3.1. Social and Medicinal Context of Drinking Mate and Tereré. The sources describe four different forms of drinking processed minced leaves and stems of yerba mate [10], but the representatives of the Paraguayan community in Misiones use two basic forms of ingesting it-a hot version called mate and a cold one: tereré. In general terms, mate is drunk all the year round, usually in the morning and in the afternoon. On hot summer days the afternoon mate may be replaced by tereré. Additionally, tereré may be drunk at noon, before lunch, and during the summer (December-March). On a few occasions, male informants mentioned that they would drink tereré the whole year round, independently of the weather. These observations stay in line with reports from rural areas of Paraguay [23, 26].

The hot beverage, mate, is normally prepared in a gourd (Lagenaria spp.) also called mate. A metal straw, bombilla, is used to ingest the extract. Industrialized yerba mate is always chosen, preferably the one with stems (con palo). According to the informants, such yerba mate does not wash away rapidly and less powder is ingested, compared to yerba mate without stems (sin palo). Small amounts of hot water $\left(77-80^{\circ} \mathrm{C}\right)$ are repeatedly poured over a serving, ca. $50 \mathrm{~g}$ of packed processed yerba mate. Yerba mate may be poured from a thermos or directly from a steel kettle. The second method normally takes place in the kitchen with a stove, where the kettle can be heated up.

The cold beverage-tereré-is drunk virtually from any container. Normally plastic, metal, or glass cups are used or those made from bamboo-like plants (Chusquea spp.). A metal or bamboo bombilla is used. Another bigger container is filled with cold water and some other additives (Figure 2). In this case, industrially processed yerba mate is also used, but there is also yerba canchada-especially processed for drinking tereré, in which leaves are crushed into large pieces.

The medicinal plants used with mate are placed in a thermos or in the gourd. Whenever hard plant parts are used, such as bark or roots, they are placed in a thermos with hot water or in a kettle. Leaves, stems, and flowers are placed directly in the gourd with yerba mate. Some Paraguayans also add sugar to mate-a spoonful is added to the yerba mate every round or every second round (the mate server starts from her/himself and then pours water into a gourd for each person in a clockwise order). When the tereré is

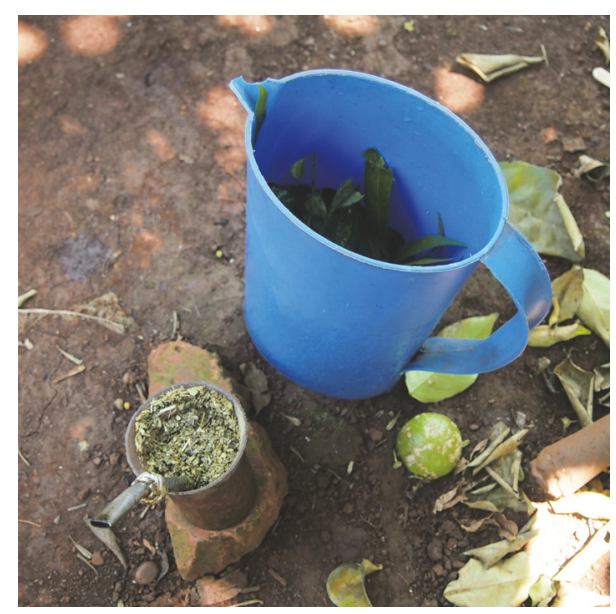

Figure 2: Tereré with kokû leaves (Allophylus edulis) prepared for a noon round on a hot summer day (Piray Km 18, Puerto Piray Municipality, Misiones, 2014).

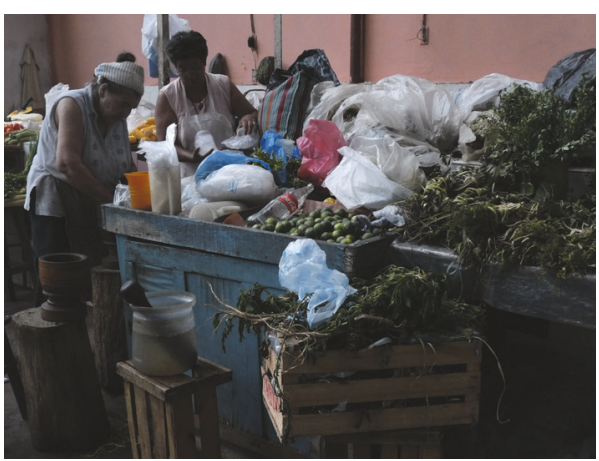

FIgUre 3: Medicinal plants, additives to tereré, and mortars in the Asunción market.

prepared, all the medicinal plants are placed in a container with cold water, and sometimes ice is added. If time permits, plants are left for several minutes to macerate. Sometimes the maceration process is accelerated, by squeezing leaves in the hands to stimulate the release of juices into the water. I have never, however, observed the use of mortars to crush medicinal plants before adding them to cold water in order to prepare the medicinal maceration for tereré-something widely practiced in Paraguayan cities, for example, Asunción and Encarnación (Figure 3).

Drinking yerba mate is social behaviour par excellence. People avoid drinking mate or tereré on their own. The afternoon mate, especially, is shared with family, neighbours, friends, and other visitors. Sometimes the addition of medicinal plants is negotiated among the participants, and in other situations the invited persons ingest the plants which the host is currently drinking with his/her yerba mate. Of anecdotal character is the story told by local doctors that Mestizo women (not necessarily of Paraguayan origin) in Misiones would add contraceptive pills to mate and then drink it with family and relatives.

Yerba mate itself is not perceived as a medicinal plant by the study community. Just one person mentioned its 


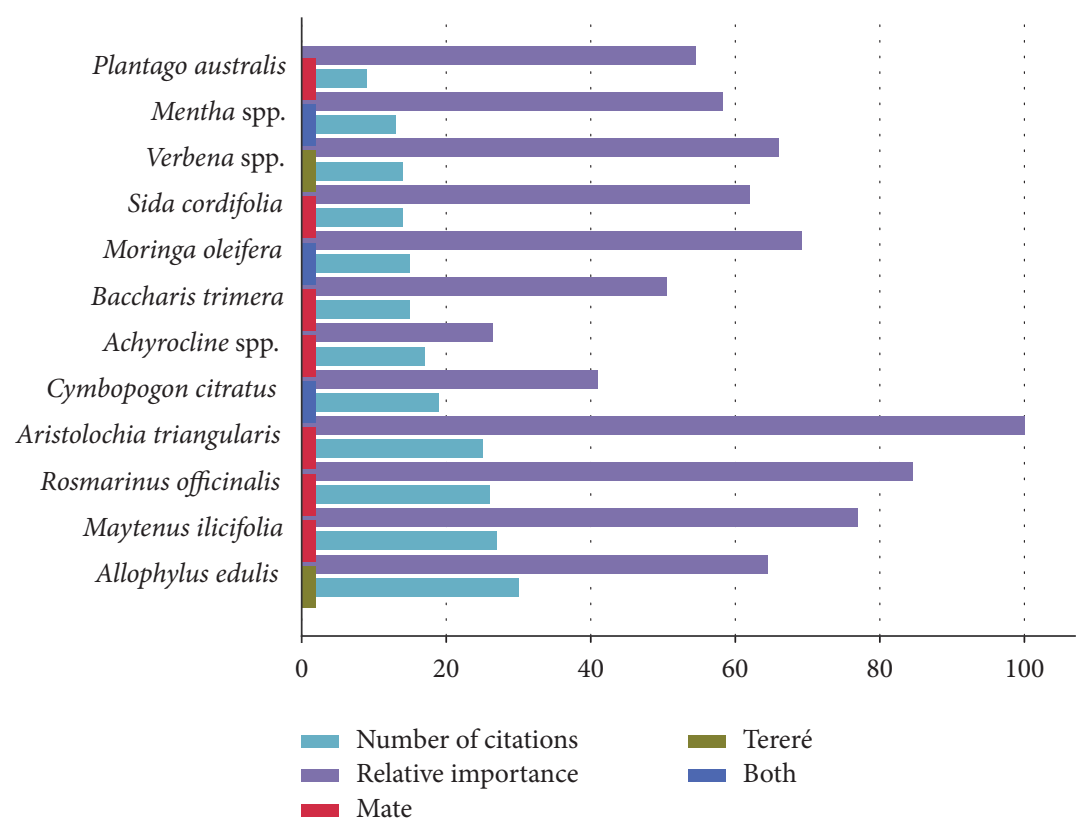

FIGURE 4: Species with the highest number of citations and relative importance value.

sole use as medicinal. Nor is it conceived as a nutraceutical ingredient; at least this was never expressed explicitly by informants. Hence, it is the medicinal plants, used together with mate or tereré, that determine the medicinal properties of a yerba mate beverage. Occasionally, plants are used to improve the taste or give a flavour to yerba mate without clear medicinal cues; rosemary (Rosmarinus officinalis), mint (Mentha spp.), and lemon grass (Cymbopogon citratus) are used in this way. The importance of the yerba mate beverage as a vehicle for medicinal plants intake was also reported in another study from Paraguay. Goyke [26] stated that, for all the top scoring plants, yerba mate was either the typical or the exclusive way people consumed them. This shows how important yerba mate is medicinally, though not by its own virtue. In this sense, these findings differ from what is reported in pharmacological literature [7].

Some epidemiological studies have reported an association between the consumption of yerba mate and increased risk of various types of cancer, including oral, laryngeal, and bladder cancer [7, 45, 46]. During my field campaign in 2014 this message was spread by radio, television, and newspapers to the general audience in Argentina. Information about the potential carcinogenic effects of drinking yerba mate produced serious concern among informants about the future of their habit. Nonetheless, the subsequent message that spread rapidly among them was that drinking mate too hot might produce cancer, which was heard with deep relief.

3.2. Characteristics of Plants Used with Mate and Tereré. The Paraguayan community in Misiones uses 97 medicinal plant species (552 UR) together with mate (58 species), tereré (17), or both (22) (Table 1). Of these 97 species, 63 are native, 30 introduced, and four naturalized. Most of the plants come from cultivation (43), followed by species gathered from the wild (39); however 12 species have been reported as cultivated by some informants and collected from ruderal areas by others. Only four species were purchased in the market or from Paraguayan ambulatory sellers-women who bring plant for sale from Paraguay through the border on the Parana River.

Allophylus edulis, kok $\hat{u}$, is the plant with the highest number of citations (30) and UR (34) (Figure 4). It is used only with tereré and is a "cold" remedy par excellence for Paraguayan people. It is also widely used in the treatment of digestive tract illnesses, hepatitis, and hypertension. Some pharmacological properties of this species are known, which largely coincide with the folk use, according to which $A$. edulis acts as a hepatoprotector (flavonoids) and angiotensin converting enzyme (ACE) inhibitor [47].

The most versatile plant species (with the highest RI value) is Aristolochia triangularis, ysypo milhombre(s). This species is only applied in mate. It is used in the treatment of nine different categories, the most important being humoral medicine (blood cleansing), but also urinary (infections) cardiovascular (hypertension), reproductive, digestive, and musculoskeletal (rheumatism) systems, and for general infections. Its use in the reproductive health category is unclear. For some informants, A. triangularis is a contraceptive or an abortifacient agent, when used in greater doses, and for others it cures venereal diseases and enhances male potency-this latter information is inscribed in the plant name ysypo [liana] milhombre(s) [thousand-men]. All informants agreed that it should be used with caution; however they could not explain what the exact side effects might be. Given its popularity among the Paraguayan community, there is surprisingly little information published on the folk medicinal use of $A$. triangularis, just two reports from Argentina [48, 49], one from Brazil [50], and a few general 


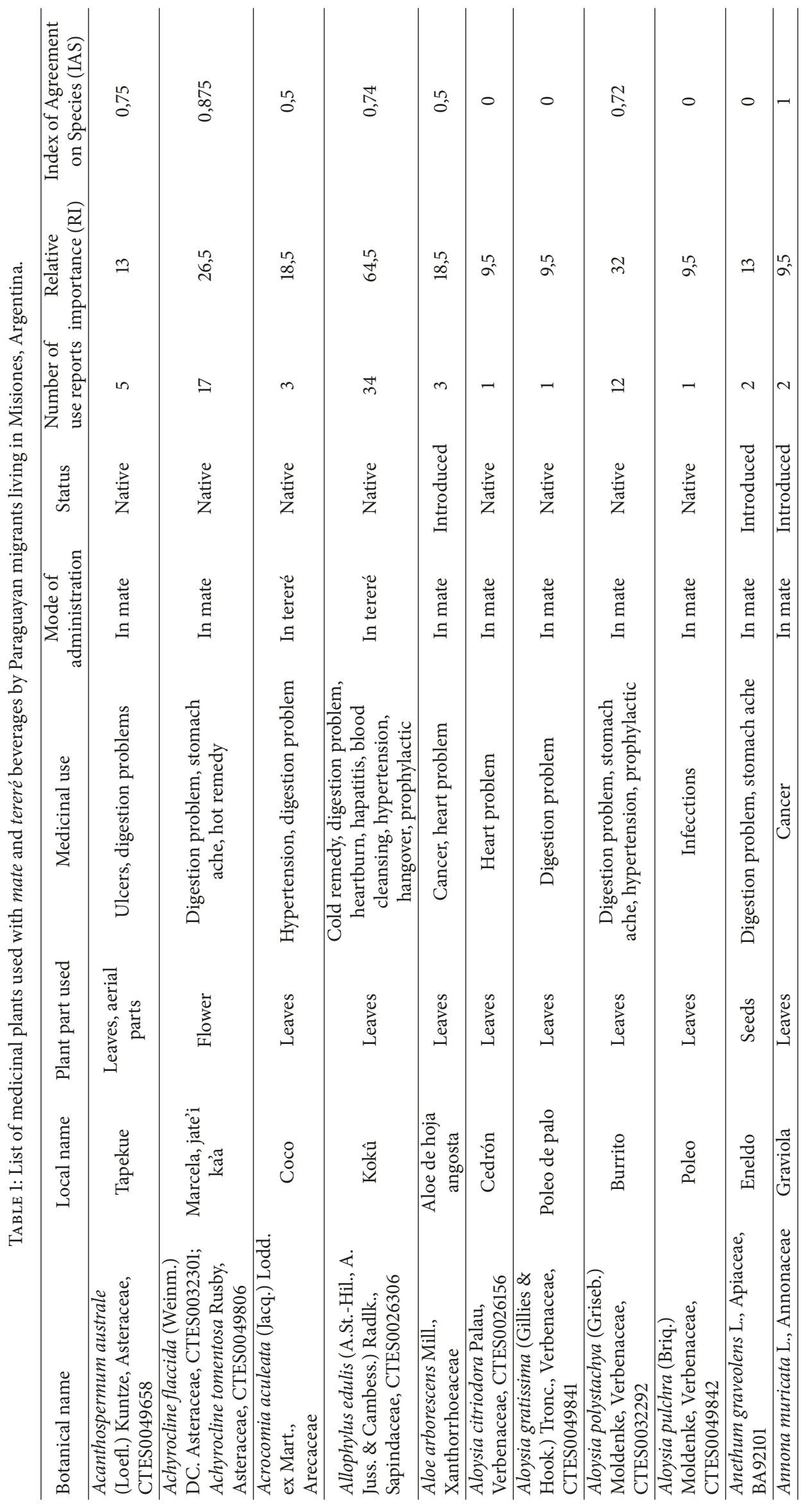




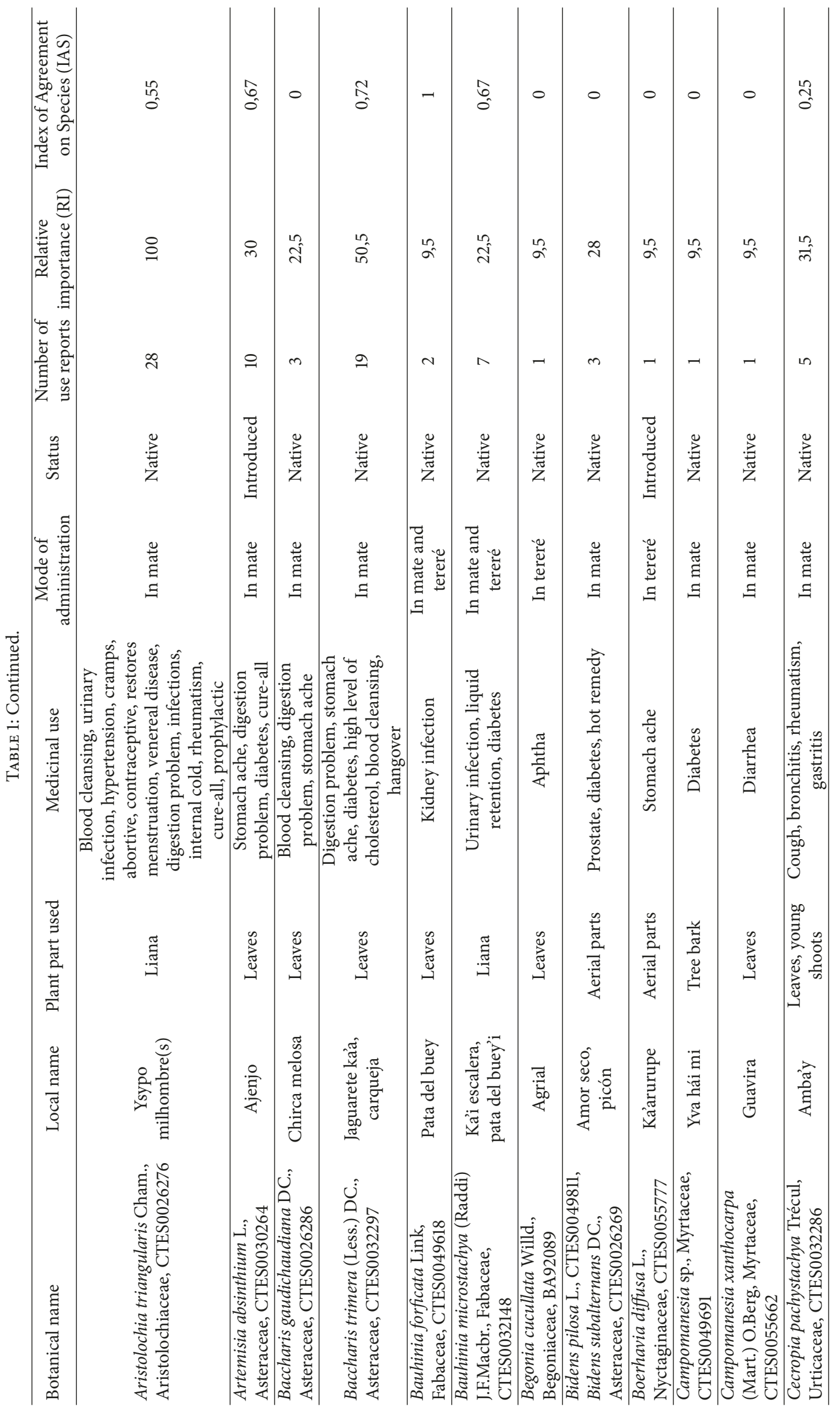




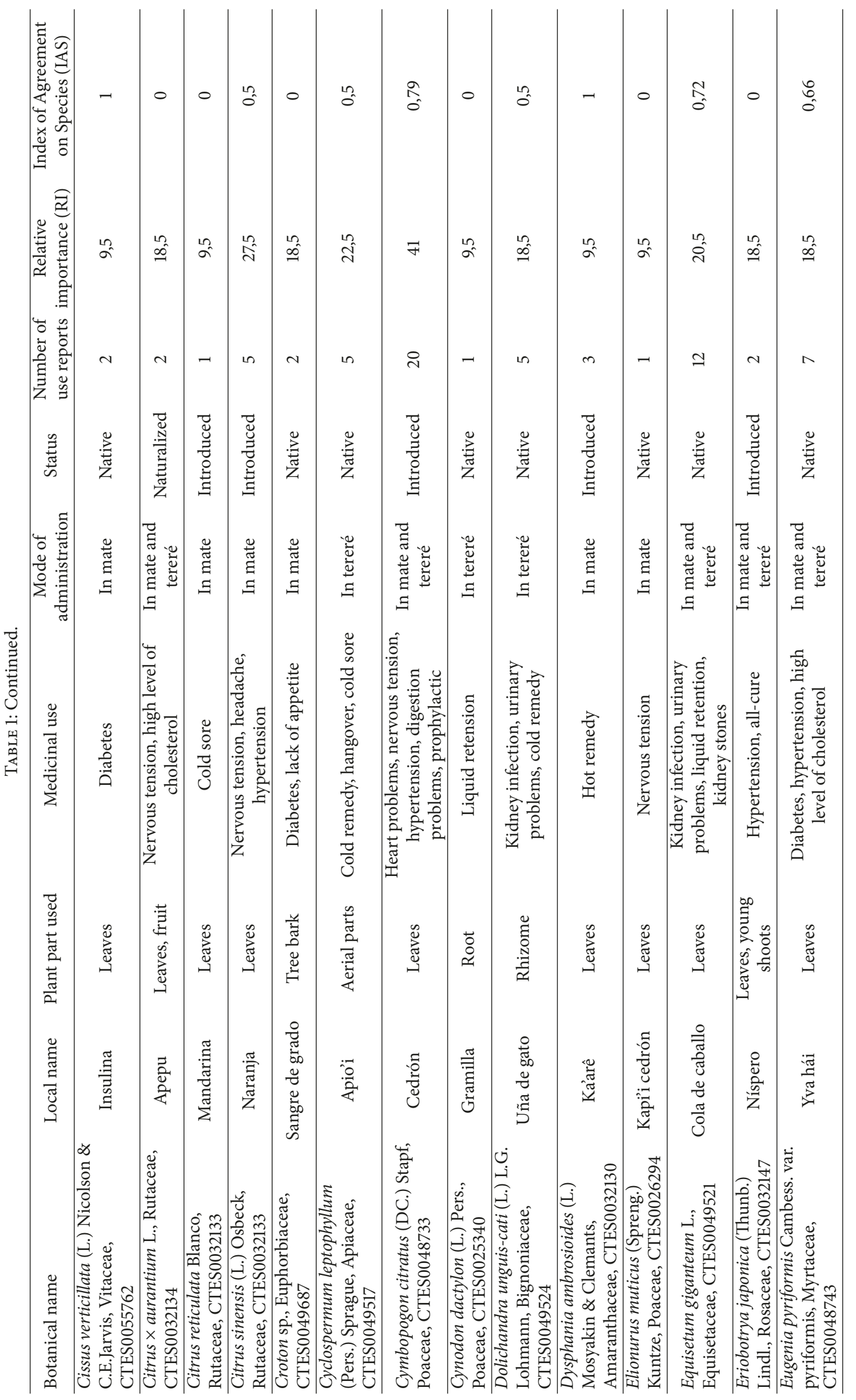




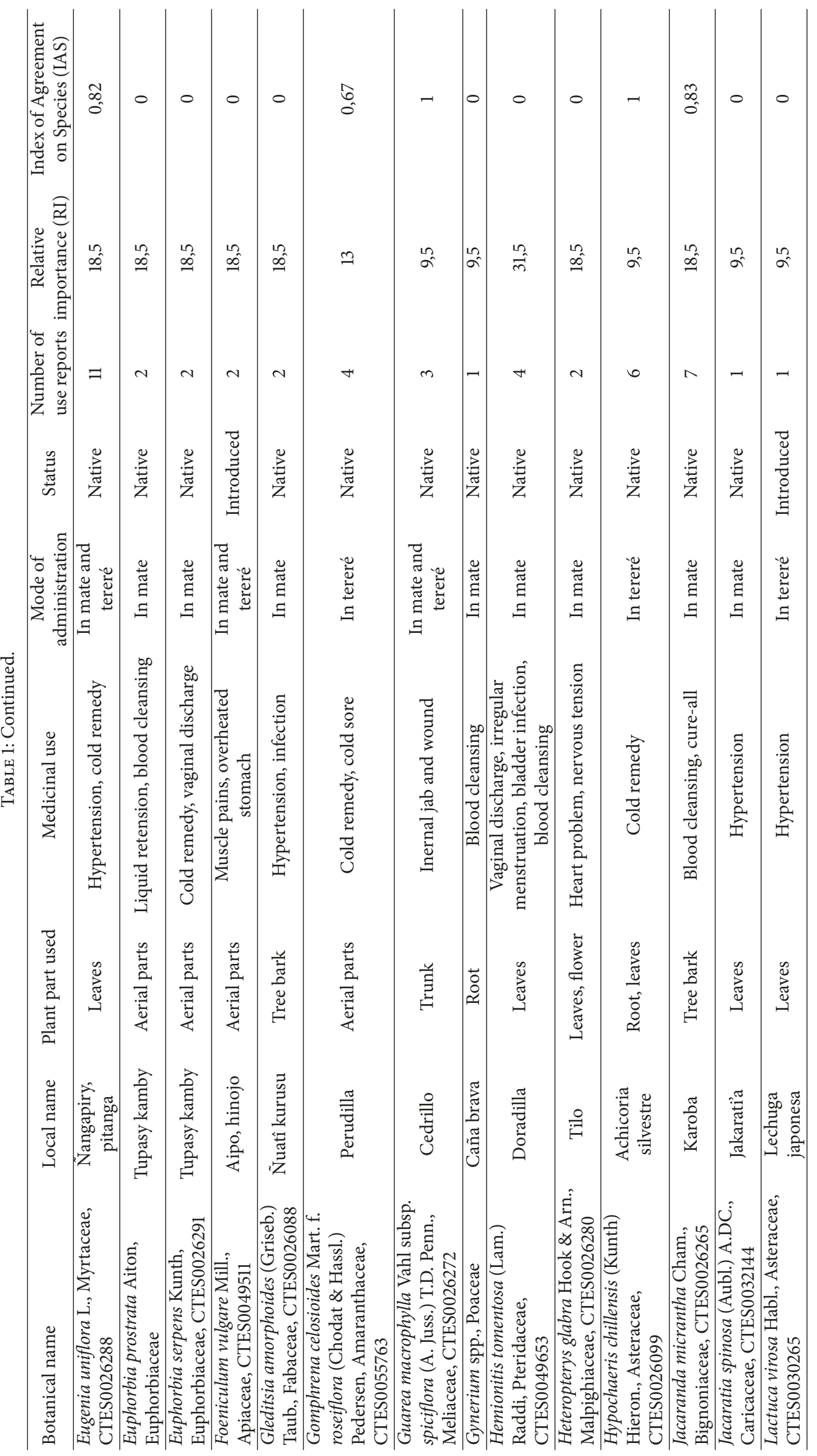




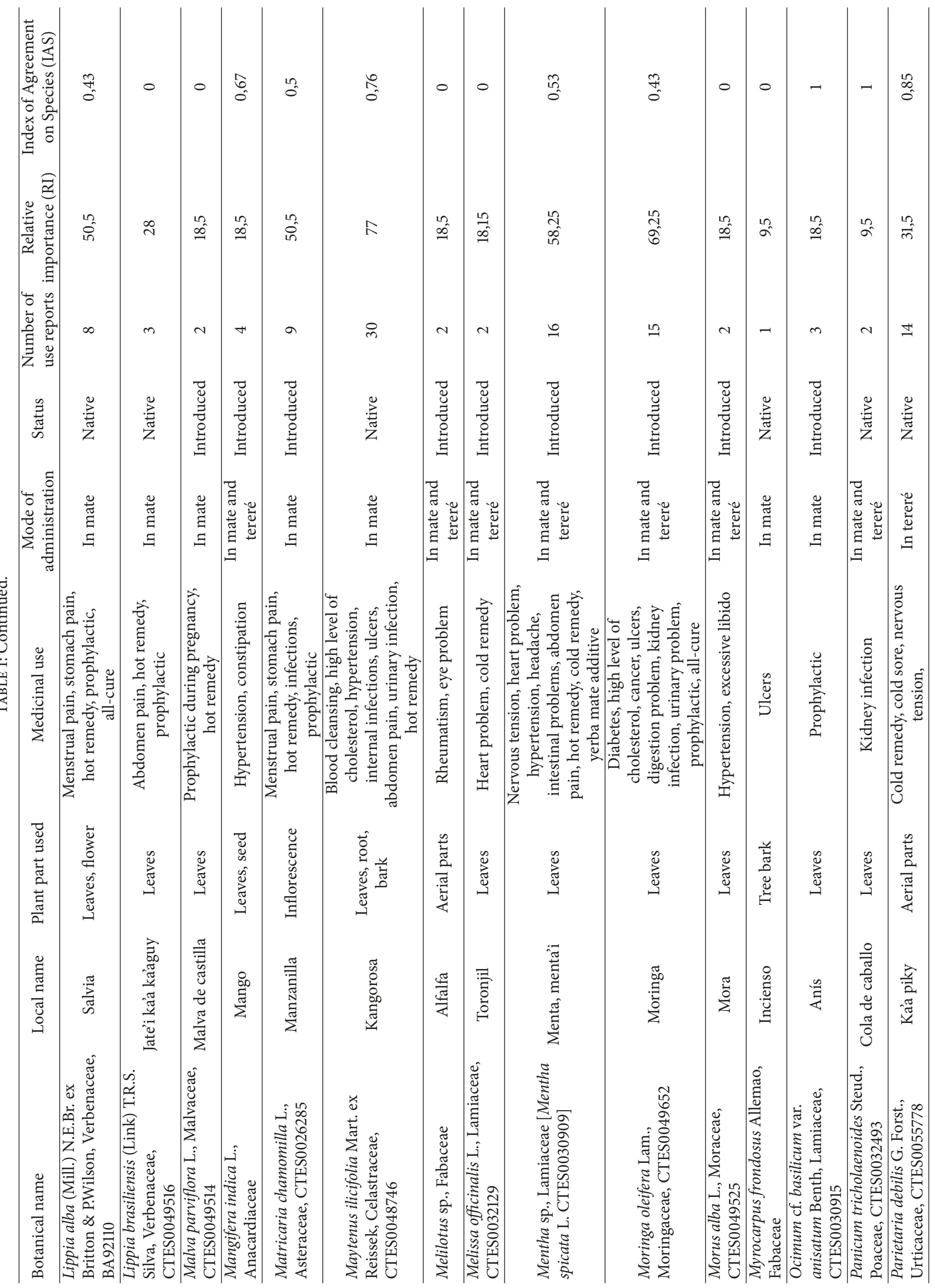




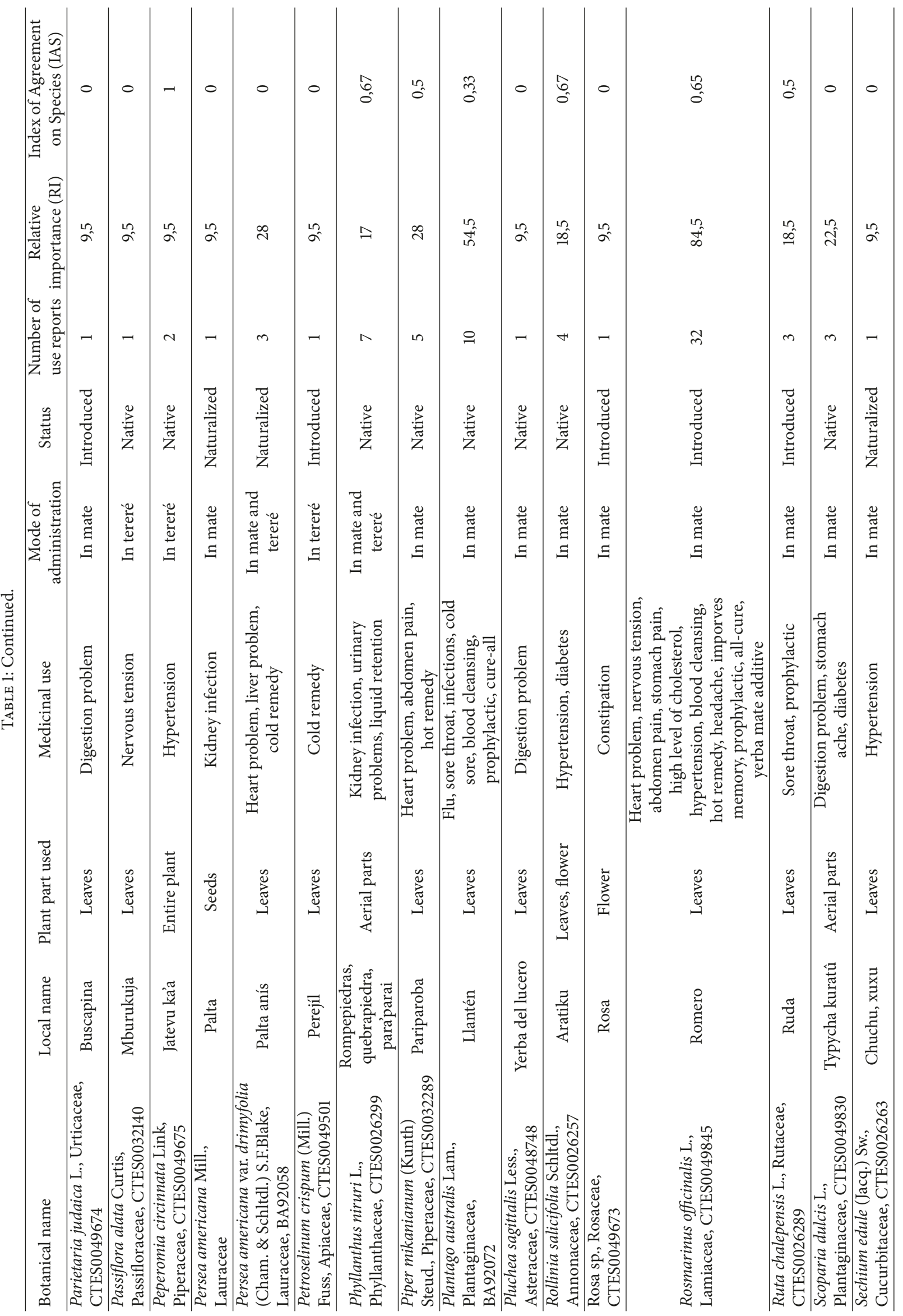




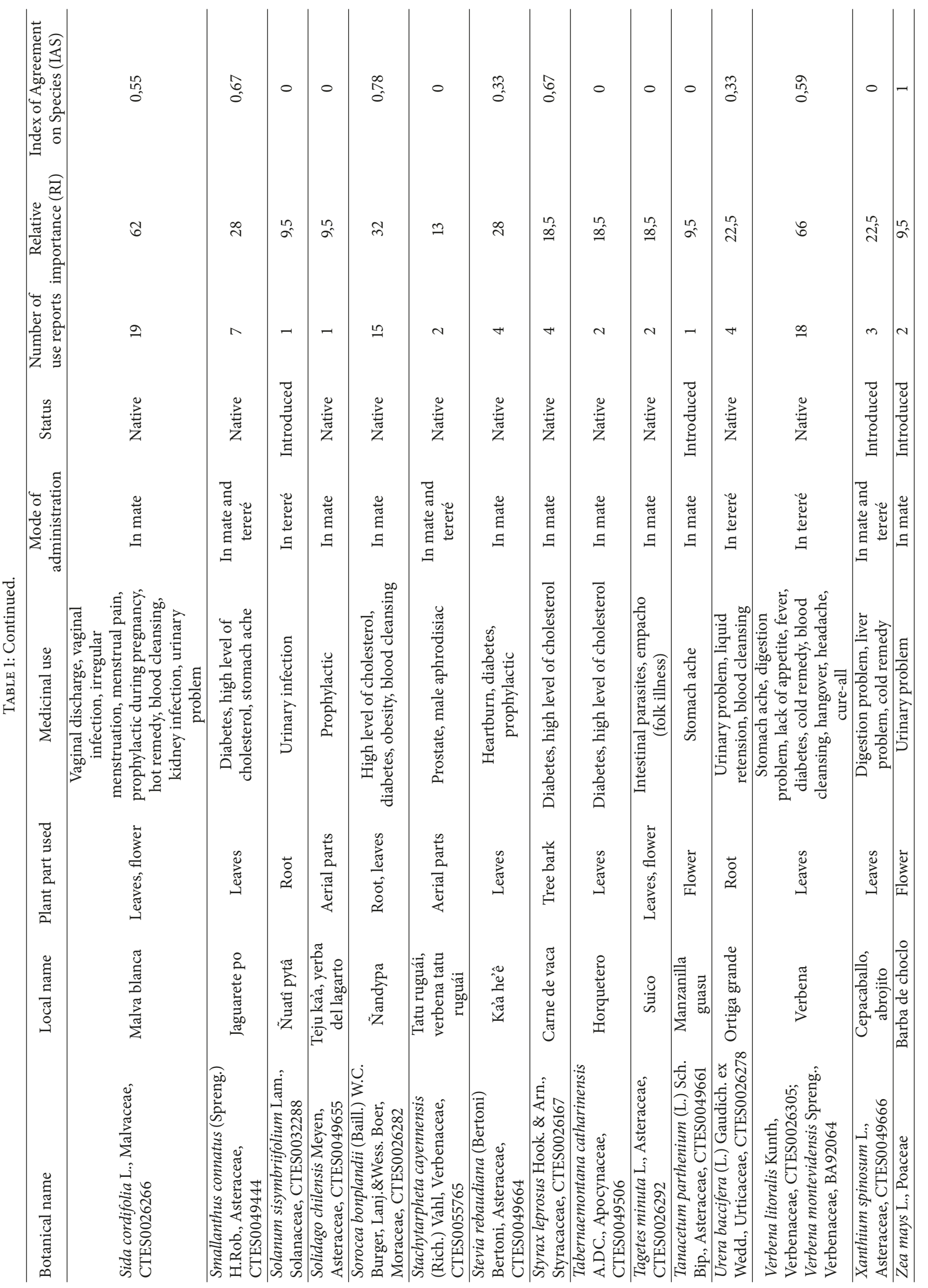


ones from South America [51]. The only pharmacologically tested properties found so far are cytotoxic [49]. The known chemical compounds are alkaloids, essential oils, lignans, terpenoids, saponins, tannins, and aristolochic acids (AAs) [52-54]. In the ethnopharmacological review by Heinrich et al. [51], different Aristolochia spp. were described, including A. triangularis. Since it also contains aristolochic acids, the consumption of the species poses a risk. In China and Europe species of Aristolochia have been associated with nephropathy, but there is a lack of data about the potential risk of renal toxicity from consuming AAs in South American literature [51].

The species with the highest consistency and consensus on use, measured by Index of Agreement on Species (IAS), were those with just one use mentioned by two or three respondents. One of the taxa with a parallel high number of citations and IAS score was Achyrocline spp. There are two species used indiscriminately within this genus: Achyrocline flaccida and Achyrocline tomentosa called jate' $i$ ka'a and marcela. These taxa are used for digestion problems and as "hot" remedy and they are always applied in mate by Paraguayan people. The importance of Achyrocline species in Paraguayan folk medicine was already highlighted by Schmeda-Hirschmann and Bordas [23]. According to pharmaceutical studies, A. flaccida possesses antiviral and antibacterial activity $[55,56]$. It contains caffeoyl derivatives, essential oils, flavonoids, and sesquiterpenes [57]. Phytochemical studies of $A$. tomentosa reported the presence of flavonoids as well as 27 mayor and trace elements $[58,59]$.

Other species from the list of the most cited ones and with the highest RI value, include native plants such as Maytenus ilicifolia, Baccharis trimera, Sida cordifolia, and Verbena litoralis/Verbena montevidensis-used indiscriminately. All of them have been studied phytochemically [60]. There are also four introduced plants on this list, all of them well studied: Rosmarinus officinalis, Cymbopogon citratus, and Mentha spp. with a long tradition of use and Moringa oleifera which has only recently (in the last 5-6 years) been incorporated by Paraguayan migrants in Misiones.

How many antidiabetic properties can be found in the plants used to treat diabetes by Paraguayan people? The study community uses 17 different plant species with mate and tereré to treat diabetes mellitus type 2. From this group only Moringa oleifera [61,62] and Scoparia dulcis [63] have been confirmed to possess antidiabetic properties. Interestingly, Paraguayan migrants, through their family and friendship channels, obtain seedlings of Cissus verticillata and Smallanthus connatus from Paraguay, as potent antidiabetic plants. C. verticillata is called insulina by them; however so far only antifungal activity has been ascribed to this species [64]. Therefore, only a small portion of the plants used as antidiabetic by Paraguayan people have been proven to possess pharmacologically tested properties for diabetes. Most probably the pharmacological action in the treatment of this health problem may be ascribed directly to Ilex paraguariensis, while informants see it in the properties of medicinal plants used with yerba mate. The question here may be whether medicinal plants with pharmacologically tested antidiabetic properties have an additive or synergetic function in the beverage.

A similar question was posed in the context of hypertension-another chronic problem for which the Paraguayan community in Misiones uses 19 different species. From this list, only Eugenia uniflora has been assigned clear hypotensive activity $[65,66]$. Indeed, this species is applied in mate and tereré with the highest frequency, with the function of decreasing blood pressure.

These two health problems have been incorporated into phytotherapy most recently by the Paraguayan people, and comparison with the pharmaceutical literature shows that Paraguayan people are still in the process of using trialand-error to find adequate herbal medicines, efficacious in the treatment of these health conditions. The relatively high number of species used for these events also indicates a personalistic approach to the search for the right drug.

\subsection{Characteristics of Illnesses Treated with Mixtures Based on} the Yerba Mate Beverage. Medicinal plants are used for their preventive and curative properties. The scope of illnesses treated with medicinal plants used in mate and tereré is very wide. Eighteen use categories have been reported, including 10 body systems (Figure 5). The most important categories are digestive, followed by humoral medicine, cardiovascular, endocrinological, and urinary categories. Interestingly, respiratory system disorders are rarely treated in this way (eight use reports for respiratory tract illnesses). The lack of dermatological problems is understandable-these ailments are treated mainly by the external application of medicinal plants.

The illnesses treated with the highest number of species are digestive problems (Figure 6). On one hand, emerging illnesses and symptoms such as hypertension, diabetes, and high levels of cholesterol are among the most important health problems treated with plants and yerba mate beverage. On the other hand, old humoral imbalances such as "hot" and "cold" syndromes and blood cleansing - another Hippocratic concept-are treated in this way. Other illnesses treated with a relatively high number of plants are urinary and kidney infections, heart problems, and nervous tension and finally menstrual problems related to women's reproductive health.

Blood cleansing is an old concept, widely used by the Paraguayan people. According to informants, it is desirable to clean the blood periodically from impurity and to make it more fluid-thick blood is considered a symptom of illness. Medicines used for high levels of cholesterol and diabetes mellitus type 2 act on a similar conceptual basis as blood cleansers for the Paraguayan people. Therefore, my working hypothesis was that, due to this conceptual similarity, Paraguayan people would adopt plants used for blood cleansing to treat new illnesses: diabetes and high levels of cholesterol. This assumption turned out to be wrong, as informants clearly distinguished the differences between these three health problems (though all concentrated in the blood). Actually, the similarities of plants used for blood cleansing and diabetes are at $19 \%$ and for blood cleansing and high levels of cholesterol are at 32\% and between diabetes and high levels of cholesterol are at 52\%, meaning that if 


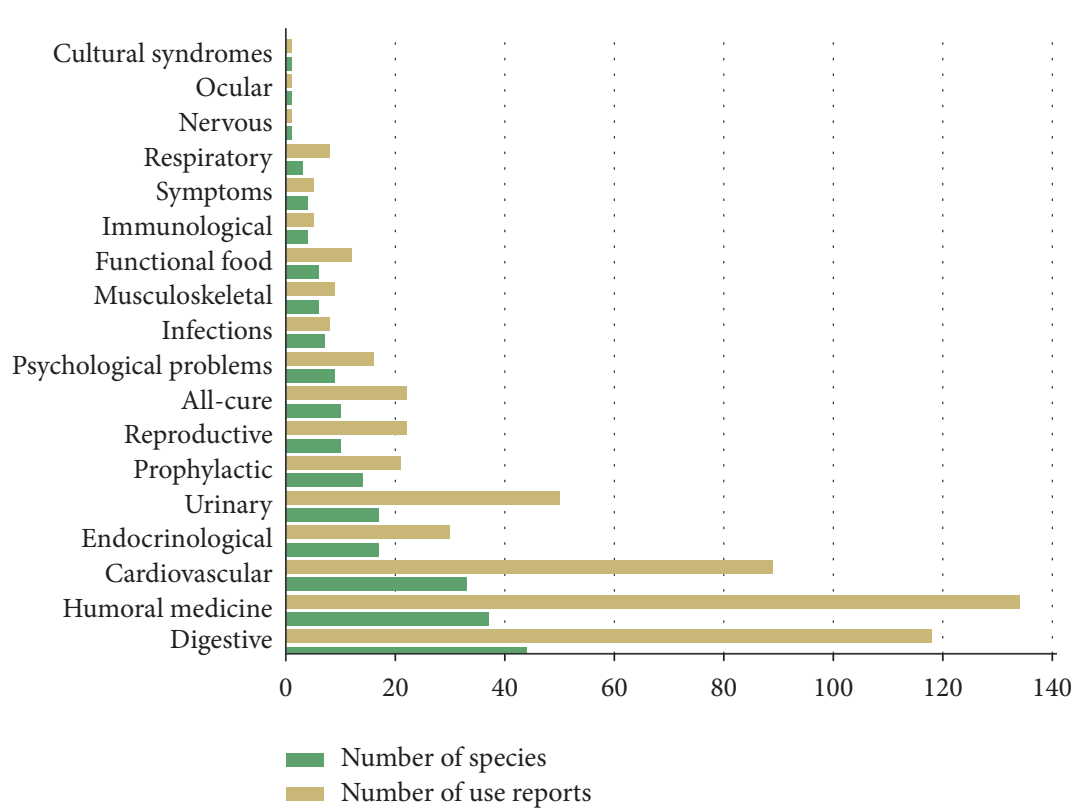

Figure 5: Medicinal categories, including body systems, for which medicinal plants are used together with the yerba mate beverage.

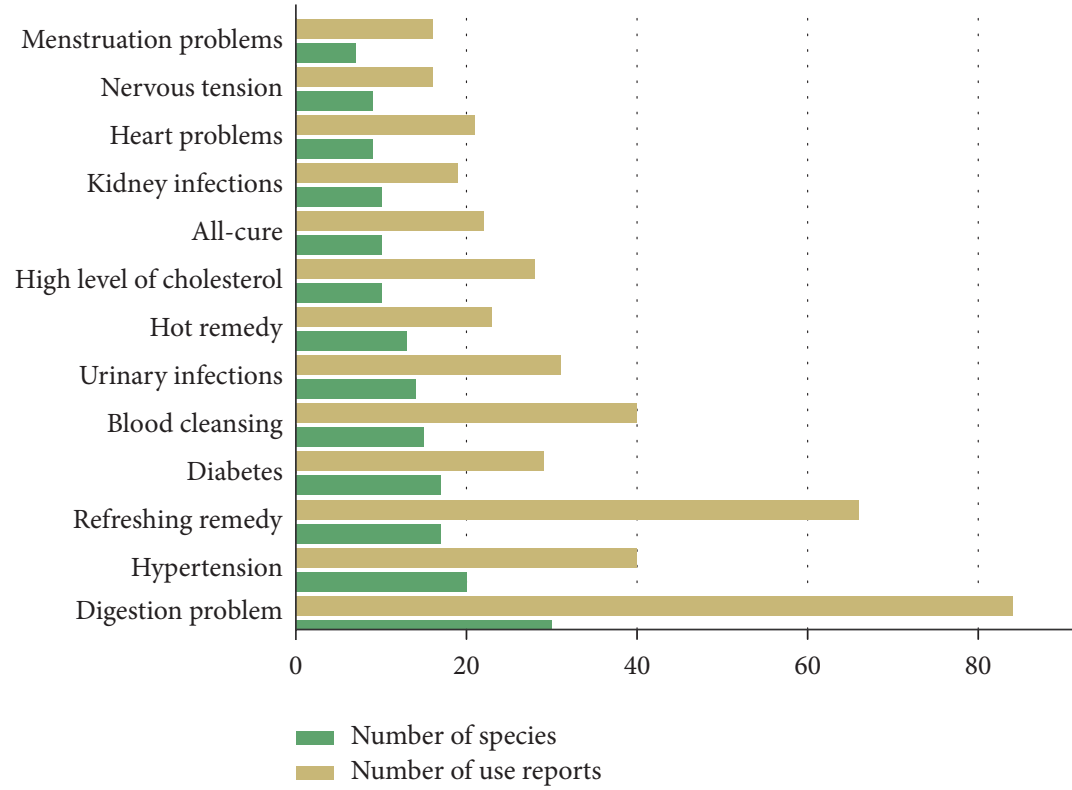

FIgURE 6: Particular illnesses treated with the highest number of species.

any cluster of plants exists, it only occurs between diabetes and high levels of cholesterol. Diabetes, of these three health problems, is treated with the greatest number of plants. Seventeen different species (29 UR) have been reported, but most of them were cited by single respondents, with only Smallanthus conatus and Sorocea bonplandii mentioned by 4 participants. Blood cleansing is treated with 15 medicinal plants (40 use reports) and there is much more consensus on the use of some of these species, compared with diabetes. Two species especially may be distinguished: Maytenus ilicifolia (15 UR) and Aristolochia triangularis (10 UR). High levels of cholesterol have a shorter trajectory of being treated with medicinal plants than blood cleansing but longer than diabetes. There are 10 species (28 UR) used to treat high levels of cholesterol, but two of them were most often reported: Sorocea bonplandii (9 UR) and Maytenus ilicifolia (7). This comparison of the consistency of/consensus on used plants is yet another point in favour of the idea that Paraguayan people are in a constant search for adequate medicinal plants to treat diabetes and, to a lesser extent, high levels of cholesterol.

Another cluster of illnesses and corresponding plants used with yerba mate extract I expected to be observed was composed of heart problems, nervous tension, and hypertension. However, the results confirm this assumption 
only partly, which may be due to the uneven number of species used in the treatment of hypertension (19 species), heart problems (9), and nervous tension (9). The greatest similarity was between heart problems and nervous tension at $44 \%$. Three introduced species were used to treat these three health problems: lemon grass, mint, and rosemary.

Similarities can be observed between plants used for kidney and urinary infections: seven different species are used for both health conditions (58\% of similarity), of which the most important ones are Bauhinia microstachya, Equisetum giganteum, and Phyllanthus niruri.

3.4. Forms of Administration. There is a certain pattern to the administration of plants with mate and tereré in respect to the illnesses that are treated. Mate is a vehicle to ingest hot remedies (for "cold" syndrome) and plants which treat women's health conditions (vaginal discharge, menstrual regulation, and pregnancy prophylaxis). The convergence of plants used in both cases is at $50 \%$. In five cases these are "hot" remedies such as Aristolochia triangularis, Lippia alba, Malva parviflora, Matricaria chamomilla, and Sida cordifolia used in both categories. Interestingly all panacea plants are employed with the hot mate drink, except Verbena spp. On the other hand, refreshing plants (for "hot" syndrome) are prepared with tereré. Most species used for urinary infections and kidney problems are used with tereré too. However, the similarity in these two medicinal categories: refreshing plants and urinary/kidney problems is very low, at 13\%, which means that in both cases quite different plants are prepared together with the tereré. Schmeda-Hirschmann and Bordas [23] also observed that Paraguayan folk medicine recognizes "hot" and "cold" remedies, whose uses dictate the manner of preparation and administration, namely, either in mate or in tereré.

According to Goyke [26], some plants are associated with either the hot or the cold version because of their flavour. Bitter and sharp flavours such as wormwood and anis are preferred in hot drinks while smooth flavours like mint, lemon grass, and saffron are preferred with the cold version [26]. Among 97 medicinal plants used by Paraguayan migrants with the yerba mate beverage, 23 are distinguished by their specific flavour (some of them contain essential oils) or taste (bitter, sour, or sweet). Fourteen of these plants are used with mate, five with tereré, and four with both. Bitter and sharp flavoured plants are used more often in mate, for example, Artemisia absinthium, Baccharis trimera and $B$. gaudichaudiana, Dysphania ambrosioides, Ruta chalepensis, or Tagetes minuta. However, bitter plants are also used with tereré: Hypochaeris chillensis, Lactuca virosa, and Verbena spp. Sour tasting plants are used only with tereré, for example, Begonia cucullata.

\section{Conclusions}

Yerba mate (Ilexparaguariensis) is not considered a medicinal plant by Paraguayan migrants living in Misiones, Argentina, by its own medicinal virtues. This plant, however, is culturally and medicinally a very important conveyor for medicinal plant intake. The Paraguayan community in Misiones uses
97 plant species in hot and cold versions of the yerba mate beverage. Most of the plants are native to the south cone of South America and come from cultivation.

There is a certain pattern of administration of plants with mate and tereré in respect to the illnesses that are treated. Mate is a vehicle to ingest hot remedies (for "cold" syndrome) and plants which treat women's reproductive health. Refreshing plants (for "hot" syndrome) are always prepared with tereré. Most species used for urinary infections and kidney problems are used with tereré too. Some plants are associated with either the hot or the cold version because of their flavour and taste. Bitter and sharp flavoured plants are more often used in mate. Sour tasting plants are used only with tereré.

The plants are used for a wide array of medicinal categories from which the digestive system and humoral concept prevail-traditionally treated with medicinal plants. On the other hand, relatively new chronic health conditions: diabetes, hypertension, and high levels of cholesterol are also treated with a large number of species. Therefore, this traditional form of administration of medicinal plants proves to be receptive for treating new health problems. Newly incorporated medicinal plants, such as Moringa oleifera or Annona muricata, are applied predominantly or exclusively with the mate beverage. The question which remains unanswered is whether medicinal plants with pharmacological properties similar to yerba mate have an additive or synergetic function in the beverage.

\section{Conflicts of Interest}

The author declares that there are no conflicts of interest regarding the publication of this paper.

\section{Acknowledgments}

The author is grateful to the study community-Paraguayan migrants in Misiones, Argentina-who generously shared their knowledge, to Bernard Kujawski and Piotr Klepacki for help with preparing the figures, and to Lukas Pawera for comments on the manuscript. The project was funded by the National Science Centre, Poland, on the basis of Decision DEC-2013/09/N/HS3/02226.

\section{References}

[1] R. Rosovsky, Contribución a La Bibliografía De La Yerba Mate, INTI, Buenos Aires, Argentina, 1983.

[2] E. Delacassa and A. L. Bandoni, "El mate," Revista de Fitoterapia, vol. 1, no. 4, pp. 257-265, 2001.

[3] P. de Montenegro, Edición de la Biblioteca Nacional de Buenos Aires, 1945.

[4] N. Bracesco, A. G. Sanchez, V. Contreras, T. Menini, and A. Gugliucci, "Recent advances on Ilex paraguariensis research: Minireview," Journal of Ethnopharmacology, vol. 136, no. 3, pp. 378-384, 2011.

[5] H. Millman, "Daily dose drinking maté in Asunción, Paraguay," Gastronomica: The Journal of Food and Culture, vol. 13, no. 4, pp. 16-21, 2013. 
[6] K. P. Burris, F. M. Harte, P. Michael Davidson, C. N. Stewart Jr., and S. Zivanovic, "Composition and bioactive properties of Yerba Mate (Ilex paraguariensis A. St.-Hil.): A review," Chilean Journal of Agricultural Research, vol. 72, no. 2, pp. 268-274, 2012.

[7] C. I. Heck and E. G. De Mejia, "Yerba mate tea (Ilex paraguariensis): a comprehensive review on chemistry, health implications, and technological considerations," Journal of Food Science, vol. 72, no. 9, pp. R138-R151, 2007.

[8] E. N. Fersan, "Syro-Lebanese migration (1880-present), push , and, pull , factors," in Migration and Mashreq, pp. 13-17, The Middle East Institute, Washington, DC, USA, 2011.

[9] K. Albala, Food Cultures of the World Encyclopaedia, Bloomsbury Food Library, Santa Barbara, Calif, USA, 2010.

[10] D. H. Markowicz Bastos, D. M. de Oliveira, R. Lobato Teixeira Matsumoto, P. de Oliveira Carvalho, and M. Lima Ribeiro, "Lima Ribeiro, "Yerba maté: Pharmacological properties, research and biotechnology," Medicinal and Aromatic Plant Science and Biotechnology, vol. 1, pp. 37-46, 2007.

[11] R. Filip, S. B. Lotito, G. Ferraro, and C. G. Fraga, "Antioxidant activity of Ilex paraguariensis and related species," Nutrition Research, vol. 20, no. 10, pp. 1437-1446, 2000.

[12] R. Filip, P. López, G. Giberti, J. Coussio, and G. Ferraro, "Phenolic compounds in seven South American Ilex species," Fitoterapia, vol. 72, no. 7, pp. 774-778, 2001.

[13] R. Heinrichs and E. Malavolta, "Composição mineral do produto comercial da erva-mate (Ilex paraguariensis St. Hil.)," Ciência Rural, vol. 31, no. 5, pp. 781-785, 2001.

[14] T. Andersen and J. Fogh, "Weight loss and delayed gastric emptying following a South American herbal preparation in overweight patients," Journal of Human Nutrition and Dietetics, vol. 14, no. 3, pp. 243-250, 2001.

[15] M. H. Pittler and E. Ernst, "Dietary supplements for bodyweight reduction: a systematic review," American Journal of Clinical Nutrition, vol. 79, no. 4, pp. 529-536, 2004.

[16] G. Schinella, J. C. Fantinelli, and S. M. Mosca, "Cardioprotective effects of Ilex paraguariensis extract: Evidence for a nitric oxidedependent mechanism," Clinical Nutrition, vol. 24, no. 3, pp. 360-366, 2005.

[17] M. Görgen, K. Turatti, A. R. Medeiros et al., "Aqueous extract of Ilex paraguariensis decreases nucleotide hydrolysis in rat blood serum," Journal of Ethnopharmacology, vol. 97, no. 1, pp. 73-77, 2005.

[18] R. Filip, T. Sebastian, G. Ferraro, and C. Anesini, "Effect of Ilex extracts and isolated compounds on peroxidase secretion of rat submandibulary glands," Food and Chemical Toxicology, vol. 45, no. 4, pp. 649-655, 2007.

[19] E. C. De Morais, A. Stefanuto, G. A. Klein et al., "Consumption of yerba mate (ilexparaguariensis) improves serum lipid parameters in healthy dyslipidemic subjects and provides an additional LDL-cholesterol reduction in individuals on statin therapy," Journal of Agricultural and Food Chemistry, vol. 57, no. 18, pp. 8316-8324, 2009.

[20] J. G. Prado Martin, E. Porto, S. M. de Alencar, E. M. da Glória, C. B. Corrêa, and I. S. Ribeiro Cabral, "Antimicrobial activity of yerba mate (Ilex paraguariensis St. Hil.) against food pathogens," Revista Argentina de Microbiología, vol. 45, no. 2, pp. 93-98, 2013.

[21] G. J. Martínez, Las plantas en la medicina tradicional de las Sierras de Córdoba, Museo de Antropología, Córdoba, Argentina, 2015, Las plantas en la medicina tradicional de las Sierras de Córdoba, Museo de Antropología.
[22] M. L. Dickel, S. M. K. Rates, and M. R. Ritter, "Plants popularly used for loosing weight purposes in Porto Alegre, South Brazil," Journal of Ethnopharmacology, vol. 109, no. 1, pp. 60-71, 2007.

[23] G. Schmeda-Hirschmann and E. Bordas, "Paraguayan medicinal compositae," Journal of Ethnopharmacology, vol. 28, no. 2, pp. 163-171, 1990.

[24] M. Kujawska, F. Zamudio, and N. I. Hilgert, "Honey-based mixtures used in home medicine by nonindigenous population of Misiones, Argentina," Evidence-Based Complementary and Alternative Medicine, vol. 2012, Article ID 579350, 15 pages, 2012.

[25] G. F. Scarpa, Las plantas en la vida de los criollos del oeste formoseño. Medicina, ganadería, alimentación y viviendas tradicionales, Asociación Civil Rumbo Sur, Buenos Aires, Argentina, 2012.

[26] N. Goyke, Traditional medicinal use in Chamorro Cué, Gral. E. Aquino, San Pedro, Paraguay [M. S. thesis], Dissertations, Master's Theses and Master's Reports, Michigan Technological University, 2017.

[27] P. Arenas and R. Azorero, "Plants of common use in Paraguayan folk medicine for regulating fertility," Economic Botany, vol. 31, no. 3, pp. 298-300, 1977.

[28] I. Basualdo, E. Zardini, and M. Ortiz, "Medicinal plants of Paraguay: Underground organs," Economic Botany, vol. 45, no. 1, pp. 86-96, 1991.

[29] I. Basualdo, E. M. Zardini, and M. Ortiz, "Medicinal plants of Paraguay: Underground Organs, II," Economic Botany, vol. 49, no. 4, pp. 387-394, 1995.

[30] N. B. Moreno, "The role of the medicinal plants in rural Paraguayan livelihoods reasons for extensive medicinal plant use in Paraguay," in Suplemento Antropológico, Revsta de Centro de Estudios Antropológicos, vol. 42, pp. 1-159, Asunción, Paraguay, 2007.

[31] M. Kujawska, N. D. Jiménez-Escobar, J. M. Nolan, and D. AriasMutis, "Cognition, culture and utility: Plant classification by Paraguayan immigrant farmers in Misiones, Argentina," Journal of Ethnobiology and Ethnomedicine, vol. 13, no. 1, article no. 42, 2017.

[32] E. Da Ponte, M. Roch, P. Leinenkugel, S. Dech, and C. Kuenzer, "Paraguay's Atlantic Forest cover loss - Satellite-based change detection and fragmentation analysis between 2003 and 2013," Applied Geography, vol. 79, pp. 37-49, 2017.

[33] P. I. Campanello, L. Montti, P. Mac Donagh, and G. Goldstein, "Reduced-impact logging and post-harvest management in the Atlantic Forest of Argentina: Alternative approaches to enhance regeneration and growth of canopy trees," Forest Management, pp. 39-60, 2009.

[34] C. Galindo-Leal and I. G. Câmara, "Atlantic Forest Hotspot Status: An Overview," in The Atlantic Forest of South: biodiversity status, threats, and outlook, C. Galindo-Leal, I. G. Câmara, and I. G. Galindo-Leal and, Eds., pp. 3-11, Island Press, Washington, DC, USA, 2003.

[35] M. Kujawska, N. I. Hilgert, H. A. Keller, and G. Gil, "Medicinal plant diversity and inter-cultural interactions between indigenous guarani, criollos and polish migrants in the subtropics of Argentina," PLoS ONE, vol. 12, no. 1, Article ID e0169373, 2017.

[36] E. R. Service, Spanish-Guarani relations in early colonial, University of Michigan Press, Ann Arbor, Mich, USA, 1954.

[37] M. F. Gawryciki, "Historia Paragwaju [History of Paraguay]," Biblioteka Iberyjska, Warszawa, 2016.

[38] B. C. Bennett and G. T. Prance, "Introduced plants in the indigenous pharmacopoeia of northern South America," Economic Botany, vol. 54, no. 1, pp. 90-102, 2000. 
[39] G. M. Foster, "Relationships between Spanish and SpanishAmerican Folk Medicine," Journal of American Folklore, vol. 66, no. 261, p. 201, 1953.

[40] E. Messer, "The hot and cold in mesoamerican indigenous and hispanicized thought," Social Science \& Medicine, vol. 25, no. 4, pp. 339-346, 1987.

[41] INDEC, Instituto Geográfico Nacional (IGN), 2010, http://www .sig.indec.gov.ar/censo2010/,web.

[42] M. Quinlan, "Considerations for collecting freelists in the field: examples from ethobotany," Field Methods, vol. 17, no. 3, pp. 219234, 2005.

[43] I. Vandebroek, "The Dual Intracultural and Intercultural Relationship between Medicinal Plant Knowledge and Consensus," Economic Botany, vol. 64, no. 4, pp. 303-317, 2010.

[44] R. Trotter and M. Logan, "Informant consensus: a new approach for identifying potentially effective medicinal plants," in Plants in Indigenous Medicine and Diet: Biobehavioral approaches, N. L. Etkin, Ed., pp. 91-112, Redgrave Publishers, Bedford Hills, NY, USA, 1986.

[45] D. Goldenberg, A. Golz, and H. Z. Joachims, "The beverage maté: A risk factor for cancer of the head and neck," Head \& Neck, vol. 25, no. 7, pp. 595-601, 2003.

[46] M. N. Bates, C. Hopenhayn, O. A. Rey, and L. E. Moore, "Bladder cancer and mate consumption in Argentina: A casecontrol study," Cancer Letters, vol. 246, no. 1-2, pp. 268-273, 2007.

[47] M. Arisawa, Y. Morinaga, Y. Nishi et al., "Chemical and pharmaceutical studies on medicinal plants in Paraguay. Constituents of angiotensin converting enzyme inhibitory fraction from 'Cocu', Allophylus edulis Radlk," Japanese Journal of Pharmacology, vol. 43, no. 1, pp. 78-80, 1989.

[48] G. L. Lorca, S. Gonzalez, F. G. A. Riglos, and J. R. Vero, "Evaluation of the cytological parameters induced by aqueous extracts of seven plants used as hypertensive in Argentina folk medicine," Acta Farmacéutica Bonaerense, vol. 21, pp. 37-42, 2002.

[49] E. Mongelli, S. Pampuro, J. Coussio, H. Salomon, and G. Ciccia, "Cytotoxic and DNA interaction activities of extracts from medicinal plants used in Argentina," Journal of Ethnopharmacology, vol. 71, no. 1-2, pp. 145-151, 2000.

[50] G. C. De Souza, A. P. S. Haas, G. L. Von Poser, E. E. S. Schapoval, and E. Elisabetsky, "Ethnopharmacological studies of antimicrobial remedies in the south of Brazil," Journal of Ethnopharmacology, vol. 90, no. 1, pp. 135-143, 2004.

[51] M. Heinrich, J. Chan, S. Wanke, C. Neinhuis, and M. S. J. Simmonds, "Local uses of Aristolochia species and content of nephrotoxic aristolochic acid 1 and 2-A global assessment based on bibliographic sources," Journal of Ethnopharmacology, vol. 125, no. 1, pp. 108-144, 2009.

[52] L. M. X. Lopes, V. D. S. Bolzani, L. M. V. Trevisan, and T. M. Grigolli, "Terpenes from Aristolochia triangularis," Phytochemistry, vol. 29, no. 2, pp. 660-662, 1990.

[53] M. L. Ambros and N. S. De Siqueira, "Phytochemical study of Aristolochia triangularis," Revista Brasileira de Farmácia, vol. 52, pp. 125-129, 1971.

[54] M. L. Ambros and N. S. De Siqueira, "Aristolochic acid in Aristolochia Triangularis," Revista Brasileira de Farmácia, vol. 52, pp. 61-63, 1971.

[55] G. García, L. Cavallaro, A. Broussalis, G. Ferraro, V. Martino, and R. Campos, "Biological and chemical characterization of the fraction with antiherpetic activity from Achyrocline flaccida," Planta Medica, vol. 65, no. 4, pp. 343-346, 1999.
[56] G. Gutkind, C. Norbedo, M. Mollerach, G. Ferraro, J. D. Coussio, and R. de Torres, "Antibacterial activity of achyrocline flaccida," Journal of Ethnopharmacology, vol. 10, no. 3, pp. 319321, 1984

[57] P. G. Lopez, G. E. Ferraro, and A. M. Broussalis, "Determination of caffeoyl derivatives content in South American species of the genus Achyrocline," Farmacéutica Bonaerense, vol. 25, pp. 571$573,2006$.

[58] G. E. Ferraro, V. S. Martino, S. I. Villar, and J. D. Coussio, "Flavonoids from Achyrocline tomentosa," Journal of Natural Products, vol. 48, no. 5, pp. 817-818, 1985.

[59] L. A. Del Vitto, E. M. Petenatti, M. E. Petenatti, S. M. Mazza, and E. J. Marchevsky, "Major and trace elements contents in crude drug and infusions of two South American species of Achyrocline (Asteraceae) named "marcelas"," Latin American Journal of Pharmacy, vol. 28, no. 4, pp. 552-559, 2009.

[60] A. Pin, G. González, G. Marin et al., Plantas medicinales del Jardín Botánico de Asunción, A. Pin and G. Céspedes, Eds., Asunción, Paraguay, 2009.

[61] F. Anwar, S. Latif, M. Ashraf, and A. H. Gilani, "Moringa oleifera: a food plant with multiple medicinal uses," Phytotherapy Research, vol. 21, no. 1, pp. 17-25, 2007.

[62] R. Gupta, M. Mathur, V. K. Bajaj et al., "Evaluation of antidiabetic and antioxidant activity of Moringa oleifera in experimental diabetes," Journal of Diabetes, vol. 4, no. 2, pp. 164171, 2012.

[63] L. Pari and M. Latha, "Antidiabetic effect of Scopariadulcis: Effect on lipid peroxidation in streptozotocin diabetes," General Physiology and Biophysics, vol. 24, pp. 13-26, 2005.

[64] L. da Silva, G. H. Onki, D. G. Agripino et al., "Bicyclogermacrene, resveratrol and antifungal activity on leaf extracts from Cissusverticillata," Revista Brasileira, vol. 17, pp. 361-367, 2007.

[65] M. T. Auricchio and E. M. Bacchi, "Eugenia uniflora L. $<$ Brazilian cherry> leaves: pharmacobotanical, chemical and pharmacological properties," Revista do Instituto Adolfo Lutz, vol. 62, pp. 55-61, 2003.

[66] E. Ferro, A. Schinini, M. Maldonado, J. Rosner, and G. S. Hirschmann, "Eugenia uniflora leaf extract and lipid metabolism in Cebus apella monkeys," Journal of Ethnopharmacology, vol. 24, no. 2-3, pp. 321-325, 1988. 


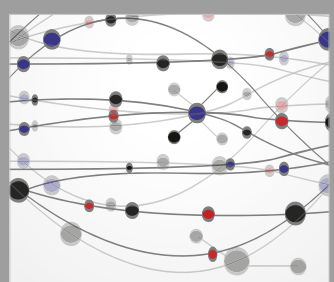

The Scientific World Journal
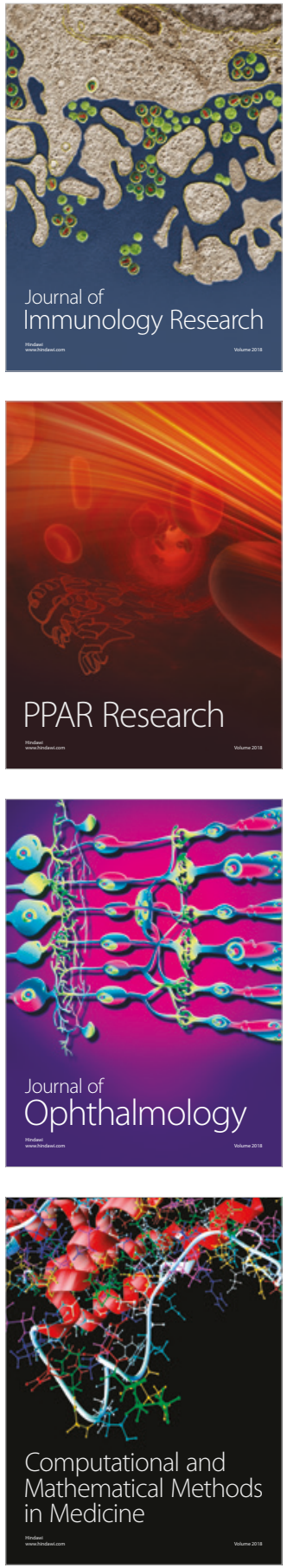

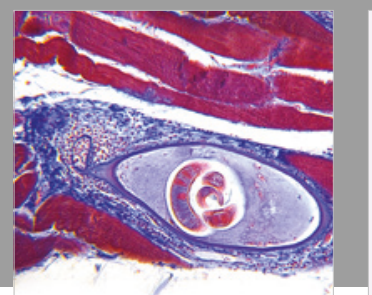

Gastroenterology Research and Practice

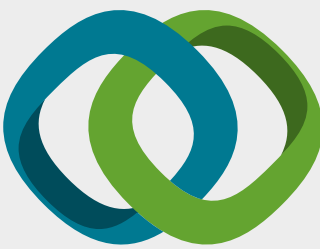

\section{Hindawi}

Submit your manuscripts at

www.hindawi.com
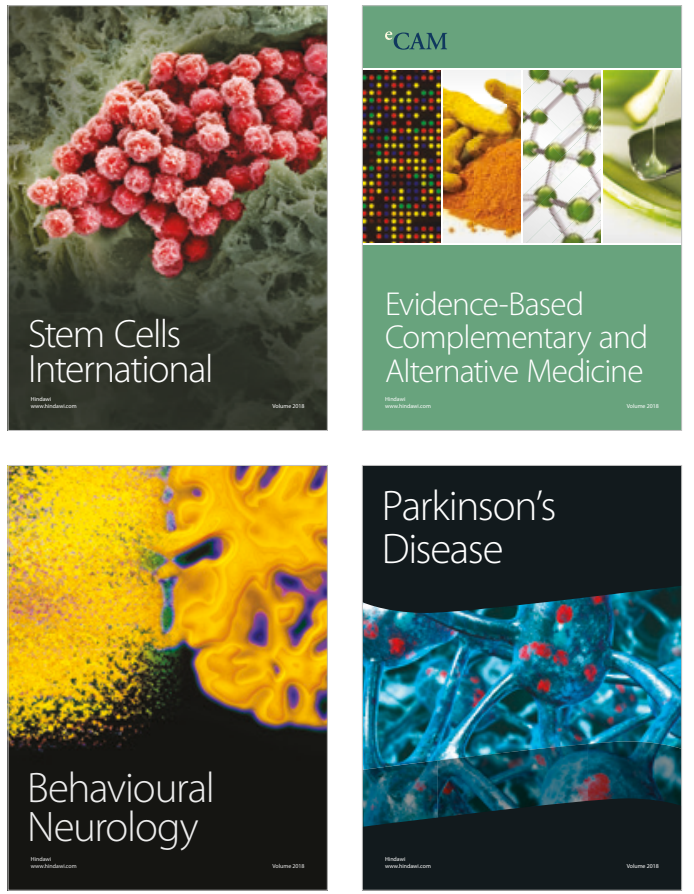

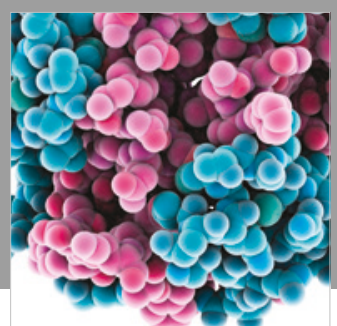

ournal of

Diabetes Research

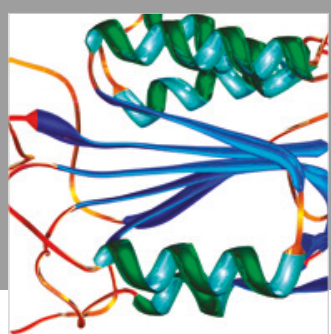

Disease Markers
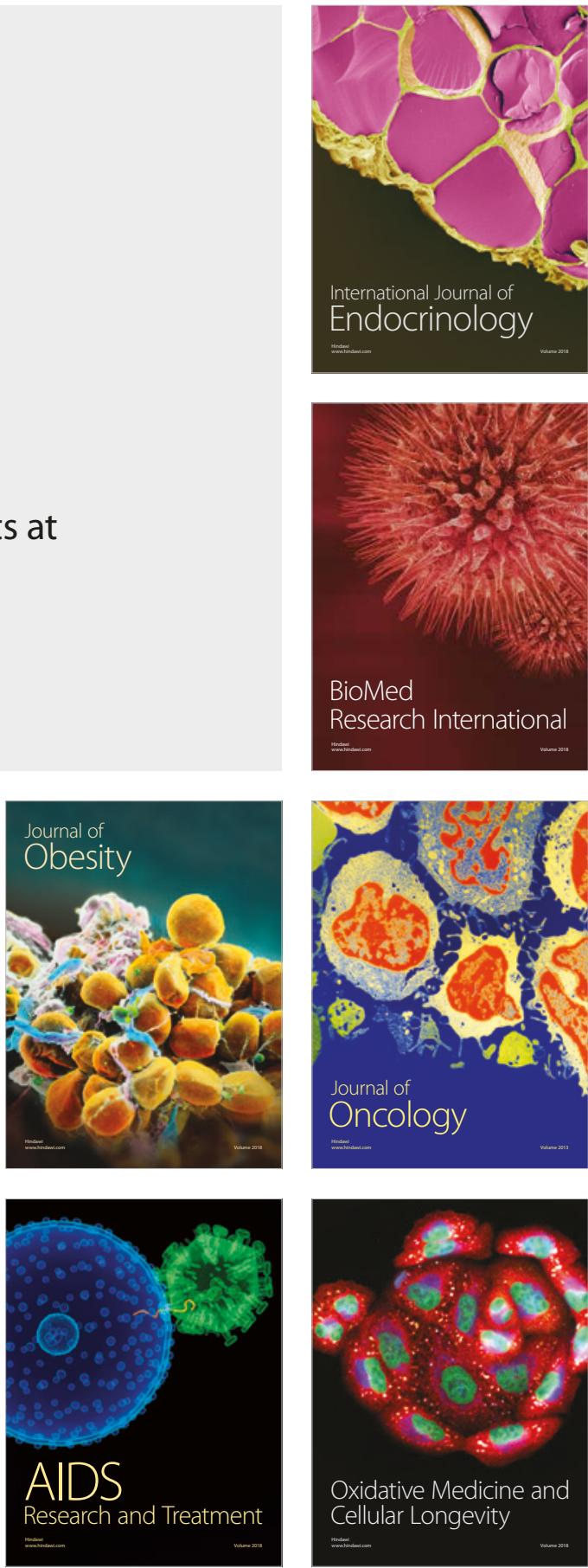